SciBX

\section{Sugar free}

\section{By Lev Osherovich, Senior Writer}

An international team has indirect genetic evidence that inhibiting the $\mathrm{C}$ isoform of fructokinase can block weight gain and insulin dysregulation in a mouse model of metabolic syndrome. The challenge now is to selectively inhibit the disease-associated form of the enzyme without compromising systemic sugar metabolism. ${ }^{1}$

Fructokinase (ketohexokinase; KHK) catalyzes the first step in fructolysis, a sequence of enzymatic steps that breaks down dietary fructose into the smaller sugars that drive cellular metabolism. The $\mathrm{C}$ isoform of fructokinase is the predominant form of the enzyme in the liver, kidney and intestine, whereas the fructokinase A splice variant is expressed throughout the body.

There has been little drug development focused on blocking early steps in sugar metabolism to treat metabolic disease, mostly because it was unclear which enzyme was the best target.

\section{"It now looks to us that inhibiting fructokinase $\mathrm{C}$ might be an ideal way to block sugar-associated metabolic syndrome." \\ - Richard Johnson, University of Colorado Denver}

greater glucose and insulin levels than wild-type controls.

"Fructokinase A was thought to be kind of an orphan enzyme without a role in fructose metabolism," said Johnson. "There's probably more fructokinase $\mathrm{A}$ in the body than fructokinase $\mathrm{C}$, but fructokinase A metabolizes fructose at a slow rate. When you knock out fructokinase A, the fructose builds up and more is delivered to the liver, where it is acted upon by fructokinase $\mathrm{C}$, thus leading to more fructose utilization and worse metabolic syndrome."

Johnson has filed a patent on targeting fructokinase C to treat metabolic disease and already has conducted screens for isoformselective fructokinase inhibitors. He hopes to start a company based on the resulting compounds. He said an alternative would be to out-license the patent.

\section{Fruit brute}

"Understanding the implications of the metabolic problems driven by fructose overconsumption is really worthwhile," said Thomas Hughes, president and CEO of Zafgen Inc. "This study suggests that inhibiting the $\mathrm{C}$ isozyme could overcome some of the problems associated with fructose-worsening of insulin resistance, dyslipidemia and poor utilization of fat."

Zafgen's beloranib (formerly ZGN-440) is an inhibitor of methionine aminopeptidase 2 (MetAP2) that is expected to enter Phase II testing for obesity this year. Hughes said inhibiting MetAP2 affects a signaling pathway

"It now looks to us that inhibiting fructokinase $\mathrm{C}$ might be an ideal way to block sugar-associated metabolic syndrome," said team leader Richard Johnson, professor of medicine, renal diseases and hypertension at the University of Colorado Denver.

\section{High-fructose diet}

Johnson's team examined the effect of a high-fructose diet on metabolic disease markers in mice lacking both the $\mathrm{A}$ and $\mathrm{C}$ isoforms and mice lacking only the A isoform. For technical reasons, it was not possible to engineer mice lacking only the $\mathrm{C}$ isoform.

Mice fed a high-fructose diet and lacking both isoforms were unable to metabolize excess fructose and excreted the sugar in their urine. Mice without the $\mathrm{A}$ isoform absorbed fructose as effectively as wild-type mice, indicating the $\mathrm{C}$ isoform alone could drive fructose metabolism.

After 25 weeks on a high-fructose diet, mice lacking both isoforms of fructokinase gained less excess fat and weight and had lower blood glucose and insulin levels than wild-type mice.

The team next looked at the effect of eliminating peripheral fructokinase A. Fructokinase A knockouts had higher levels of intrahepatic fructose and fructose degradation products than wildtype controls, indicating that the liver version of the enzyme was doing double duty.

Indeed, the absence of peripheral fructokinase function led to higher fructose utilization in the liver and thus accelerated metabolic disease. Fructose-fed fructokinase A knockouts put on more weight and had that regulates energy downstream of fructokinase.

What's missing, said Hughes, is a direct demonstration that inhibiting fructokinase $\mathrm{C}$ alone can reduce fructose metabolism. In the absence of $\mathrm{C}$ isoform-specific knockout mice, the best way to do such an experiment may be with a small molecule inhibitor that is selective for the $\mathrm{C}$ isoform.

Hughes also said the high levels of plasma fructose found in mice lacking both forms of fructokinase may pose a potential safety problem. He said high blood sugar levels "raise a concern about the formation of advanced glycation end products," which are sugar-protein adducts that compromise renal function and contribute to tissue damage in type 2 diabetes.

"Fructose is a much better glycating agent than glucose, so if you increase the levels of fructose you would expect to increase levels of advanced glycation end products, which are bad in diabetes," said Hughes.

It's unclear how selectively blocking fructokinase $\mathrm{C}$ would affect formation of such advanced glycation end products (AGEs). For now, Hughes suggested the team monitor AGE levels in mice lacking both forms of the enzyme and watch for signs of diabetes-like tissue damage.

Johnson countered that "people who lack fructokinase due to a hereditary condition live healthy lives, suggesting that this is a safe target."

He also noted that selectively inhibiting fructokinase C, while leaving fructokinase A intact, should prevent excess fructose accumulation in 


\section{ANALYSIS}

\section{TARGETS \& MECHANISMS}

\section{"The results lead to ideas around a diagnostic test that could identify people more likely to be at risk due to the genetic or epigenetic states of their fructokinase genotypes." \\ -Charles Hart, \\ Threshold Pharmaceuticals Inc.}

correlate with disease severity.

"The results lead to ideas around a diagnostic test that could identify people more likely to be at risk due to the genetic or epigenetic states of their fructokinase genotypes," said Hart.

Threshold dropped development of 2-deoxyglucose (2-DG), an inhibitor of glycolysis for solid tumors, in 2011 because of strategic reasons and lack of "sufficiently dramatic clinical outcomes", said Hart.

Last year, Johnson \& Johnson reported that it had compounds that inhibited fructokinase. ${ }^{2}$ However, a company spokesperson said J\&J discontinued preclinical development of those molecules for undisclosed reasons. J\&J did not disclose whether its compounds could discriminate between the two isoforms of fructokinase.

Also last year, AstraZeneca plc discontinued development of a trio of compounds that activated glucokinase (GCK; GK), which is an enzyme related to fructokinase that initiates the entry of glucose into glycolysis. AZD1656, the most advanced of these compounds, was in Phase II testing for diabetes and obesity.

Osherovich, L. SciBX 5(13); doi:10.1038/scibx.2012.324

Published online March 29, 2012

\section{REFERENCES}

1. Ishimoto, T. et al. Proc. Natl. Acad. Sci. USA; published online Feb. 27, 2012; doi:10.1073/pnas.1119908109

Contact: Richard J. Johnson, University of Colorado Denver, Aurora, Colo. e-mail: richard.johnson@ucdenver.edu

2. Zhang, X. et al. Bioorg. Med. Chem. Lett. 21, 4762-4767 (2011)

\section{COMPANIES AND INSTITUTIONS MENTIONED}

AstraZeneca plc (LSE:AZN; NYSE:AZN), London, U.K. Johnson \& Johnson (NYSE:JNJ), New Brunswick, N.J. Threshold Pharmaceuticals Inc. (NASDAQ:THLD), South San Francisco, Calif.

University of Colorado Denver, Aurora, Colo.

Zafgen Inc., Cambridge, Mass. 